\title{
Bilateral papillary cystadenoma of the mesosalpinx: a rare manifestation of Von Hippel-Lindau disease
}

\author{
Diana Bätschmann Zanotelli • Elisabeth Bruder • \\ Edward Wight $\cdot$ Carolyn Troeger
}

Received: 7 December 2009 / Accepted: 25 January 2010 / Published online: 16 February 2010

(C) Springer-Verlag 2010

\begin{abstract}
We report a rare case of a woman with bilateral papillary cystadenomata of the broad ligament with von Hippel-Lindau disease (VHL) (other manifestations: capillary hemangioblastomas of the spinal cord). Patient surveillance is important, because in the course of VHL-associated tumors malignant lesions may arise that are relevant for the prognosis.
\end{abstract}

Keywords Von Hippel-Lindau disease · Papillary cystadenoma of the mesosalpinx

\section{Introduction}

Von Hippel-Lindau disease (VHL) was first described in 1926 as an inherited disease, characterized by tumors of the retina, brain, kidney, adrenal gland, and pancreas. Recently the VHL gene was identified as a tumor suppressor gene on the short arm of chromosome 3 (3p25-26). VHL disease is an autosomal dominantly inherited multisystemic tumor syndrome due to a gene mutation with an incidence of one in 36,000 live births [1]. In $20 \%$ of cases de novo mutations occur [2]. The mutations cause a situation analogous to hypoxia with an increase in various growth and angiogenic factors [3].

Affected individuals are at high risk for developing various benign and malignant tumors. Lesions in VHL disease

D. B. Zanotelli $\cdot$ E. Wight · C. Troeger $(\square)$

Department of Obstetrics and Gynecology,

University Hospital Basel, Spitalstrasse 21,

4031 Basel, Switzerland

e-mail: ctroeger@uhbs.ch

E. Bruder

Institute of Pathology,

University Hospital Basel, Basel, Switzerland tend to be multiple and bilateral in paired organs (Table 1) $[1,4-6]$. Though rarely described in the literature $(n=4)$, a benign adnexal papillary tumor of probable mesonephric origin (APMO) is highly significantly associated with VHL disease. The WHO classification differentiates between two main clinical types, based on the risk for developing a pheochromocytoma and/or renal cell carcinoma and is related to the type of mutation (Table 2) [1, 7].

Most tumors develop at younger age, i.e. between 20 and 40 years. The penetrance of the disease is about $96 \%$ by the age of 60 years with renal cell cancer in $69 \%$, retinal tumor in $70 \%$ and cerebellar hemangioblastoma in $85 \%[1,6]$.

Metastases determine the prognosis and can be found in patients with renal cell carcinoma, rarely in pheochromocytomas or islet cell tumors. Intracerebral hemorrhages due to bleeding from carcinomas or hemangioblastomas of the brain are the main cause of death [4].

Improved surveillance, earlier diagnosis of the lesions with modern imaging (MRI), improvements in treatment and increased knowledge of this disease have resulted in an improved prognosis and reduced rates of complications. An interdisciplinary team is beneficial for optimal assessment, treatment, and follow-up. It is also recommended that the family of the index patient is examined, because individuals with a predisposition for an inherited tumor syndrome, such as VHL disease, benefit from early screening at around 11 years of age, ophthalmologic examination, catecholamine testing, and magnetic resonance imaging [4].

\section{Case report}

A woman aged 23, nulligravida, underwent a gynecological examination at our institution, because of lower abdominal pain of unclear etiology. Ultrasonographic examination 
Table 1 Typical VHL lesions

\begin{tabular}{|c|c|c|}
\hline & $\begin{array}{l}\text { Frequency } \\
(\%)\end{array}$ & $\begin{array}{l}\text { Onset } \\
\text { (years) }\end{array}$ \\
\hline \multicolumn{3}{|l|}{ CNS } \\
\hline Retinal hemangioblastoma & $10-72$ & $25-33$ \\
\hline \multicolumn{3}{|l|}{ Endolymphatic sac tumor } \\
\hline \multicolumn{3}{|l|}{ Craniospinal hemangioblastoma } \\
\hline \multicolumn{3}{|l|}{ Visceral } \\
\hline Renal cell carcinoma & $25-70$ & $30-39$ \\
\hline \multicolumn{3}{|l|}{ Pheochromocytoma } \\
\hline \multicolumn{3}{|l|}{$\begin{array}{l}\text { Pancreatic tumor } \\
\text { (cyst, serous cystadenomas, } \\
\text { neuroendocrine tumor) }\end{array}$} \\
\hline $\begin{array}{l}\text { Cystadenoma of epididymis } \\
\text { or broad ligament }\end{array}$ & & \\
\hline
\end{tabular}

Table 2 WHO classification of VHL disease

\begin{tabular}{cc} 
Type 1 & $\begin{array}{c}\text { Low risk for pheochromocytoma, hemangioblastoma, } \\
\text { renal cell cancer, pancreatic neoplasms and cysts }\end{array}$ \\
Type 2A & $\begin{array}{c}\text { Pheochromocytoma, hemangioblastoma, low risk } \\
\text { for renal cell carcinoma and pancreatic tumors }\end{array}$ \\
Type 2B & $\begin{array}{c}\text { Pheochromocytoma, hemangioblastoma, high risk } \\
\text { for renal cell carcinoma and pancreatic tumors }\end{array}$ \\
Type 2C & $\begin{array}{c}\text { Predominantly pheochromocytoma, very limited } \\
\text { risk of hemangioblastoma and of renal cell cancer }\end{array}$ \\
\hline
\end{tabular}

revealed a partly solid, partly cystic mass of $3.5 \mathrm{~cm}$ diameter in the right adnexal region (Fig. 1). Ca-125 was within normal limits $(15.9 \mathrm{U} / \mathrm{ml})$. Laparoscopy was performed and a cystic tumor was found in the right mesosalpinx (Fig. 2) and removed completely. In the left mesosalpinx a smaller ( $8 \mathrm{~mm}$ diameter) cystic tumor was detected and subsequently removed. On both sides ovaries and fallopian tubes were unaffected and could be preserved.

Histological examination revealed bilateral clear cell papillary cystadenomas of the mesosalpinx. The tumors were composed of tightly packed papillae with loose or dense fibrous cores, covered by a monolayered epithelium (Fig. 3). These findings prompted genetic testing on the adnexal papillary tumor of probable mesonephric origin (APMO) and showed a point mutation P86L on the exon 1 of the VHL gene. The patient has been counseled accordingly.

Five years before, the patient had undergone a laminectomy of thoracic vertebrae 2 and 3 for symptomatic capillary hemangioma with insertion of syringoperitoneal drainage (Fig. 4). The size of the hemangioblastoma of the thoracic vertebral column at that time was $3 \times 1.5 \mathrm{~cm}$. During follow-up, MRI now shows two additional similar lesions at the cervical vertebral body IV $(1 \times 1 \mathrm{~cm})$ and the sacral body which until now have been treated conserva-

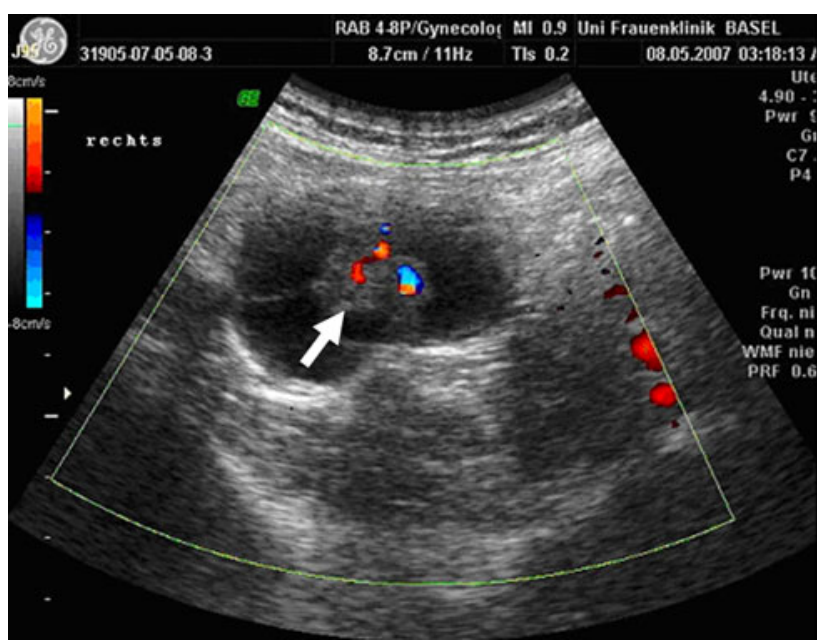

Fig. 1 Doppler ultrasonographic scan of the papillary cystadenoma of the right adnex region (arrow indicates the papillary part of the tumor)

tively and examined every 6-12 months (picture not shown).

\section{Comment}

Papillary cystadenomas of the mesosalpinx are rare benign lesions. Bilaterality can be a diagnostic hint of VHL disease [1]. Surgery is necessary if symptoms occur. The APMO is histologically identical to the papillary cystadenoma of the epididymis in males, where it is usually diagnosed easier $[8,9]$. With regard to long-term consequences proper follow-up concerning renal cell carcinoma is mandatory, because the risk of metastatic disease increases with tumor size [4]. Vice versa proper surveillance of the gonadal region in VHL patients is necessary, since metastasis of renal cell carcinomas to the adnexae and epididymes are described. These metastases might even develop within existing VHL lesions, such as in hemangioblastoma of the brain or in cystadenomas of the epididymis, the adrenal gland, and in the gall bladder [7].

The histological similarity between papillary cystadenoma and renal cell carcinoma can be explained by the similar phylogenetic origin of renal tubules, ductules efferentes, and mesonephric remnants [10]. Thus papillary cystadenomas can be found intra- and extraperitoneally in remnant parts of the mesonephric duct including the broad ligament, the mesosalpinx, along the lateral wall of the uterus and in the wall of the vagina $[11,12]$. There are reports on VHL tumors of both Mullerian and Wolffian origin containing numerous glands (characterized by tall columnar cells) $[9,13]$. Interestingly, these lesions might be associated with a histological identical papillary middle ear/temporal bone tumor [11]. 
Fig. 2 Intraabdominal inspection of the tumors (arrow) (organs as indicated: $a$ uterus, $b$ right fallopian tube, $c$ right ovary)

Fig. 3 Histopathology (HE staining) revealed a cystic tumor with papillary excrescences. Tumor papillae are lined by a monolayer of cuboid to columnar epithelial cells with monomorphic oval nuclei and a rim clear cytoplasm
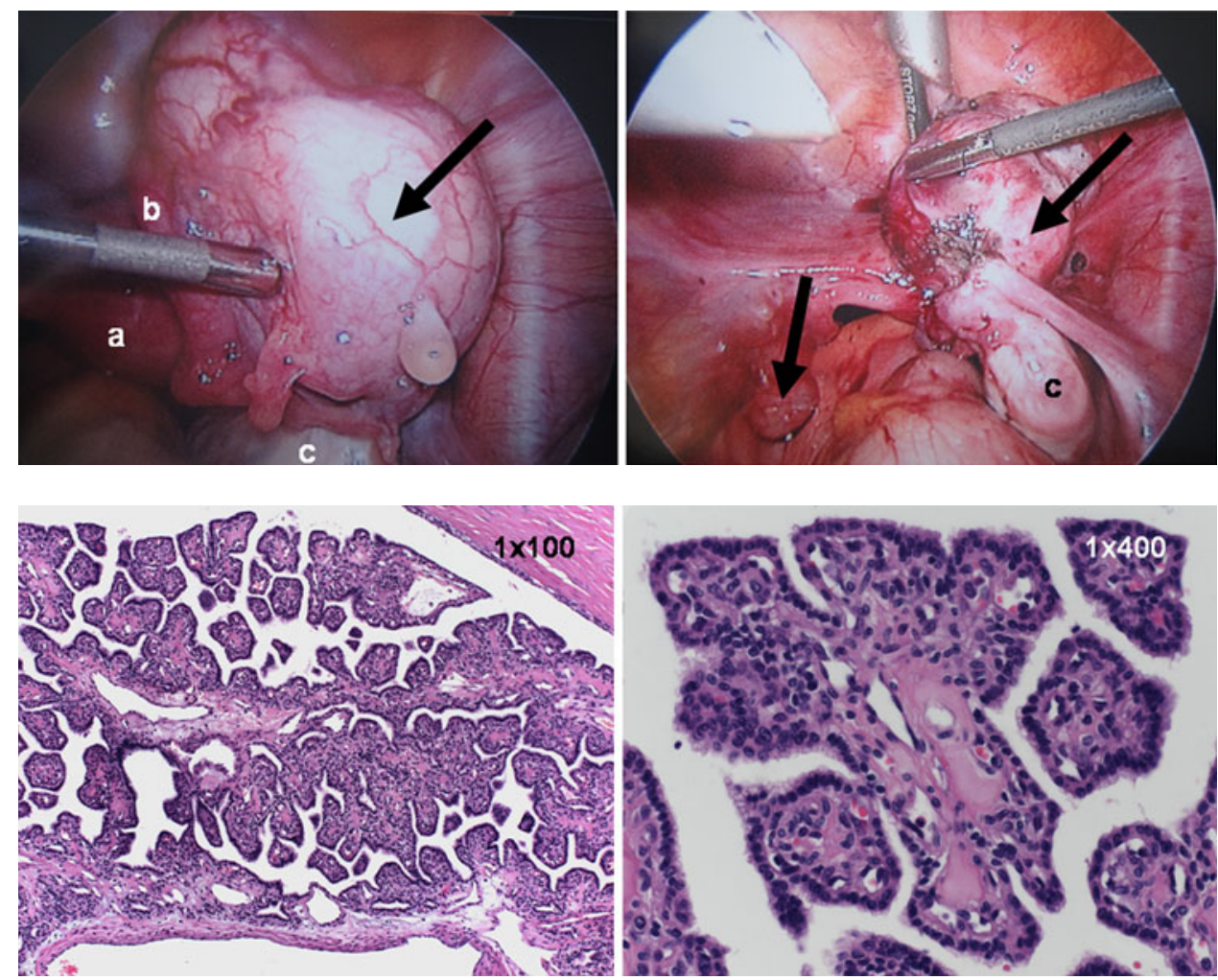

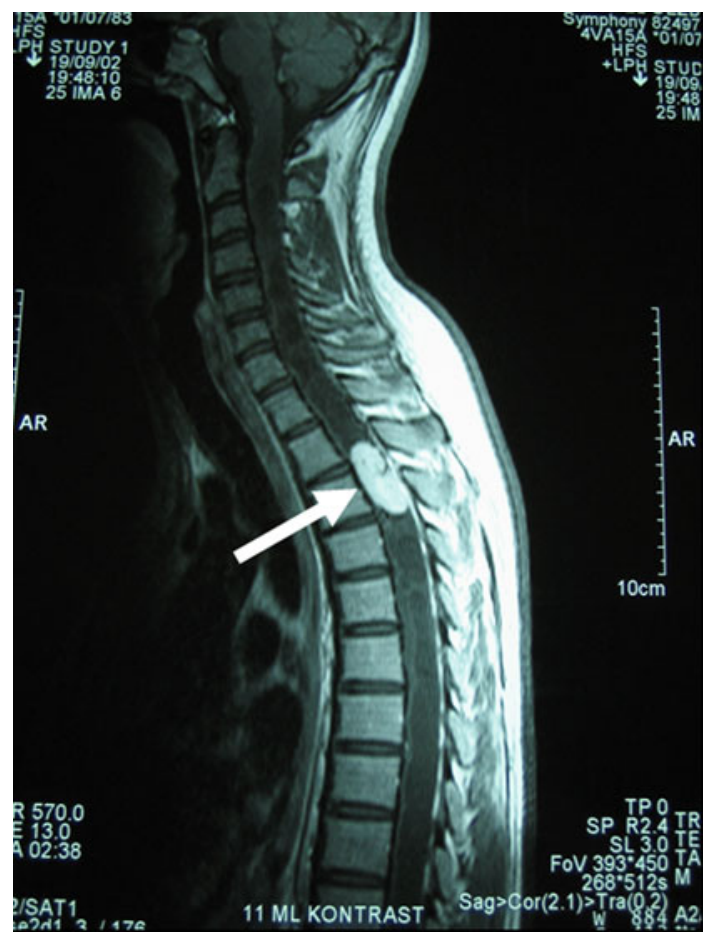

Fig. 4 Magnetic resonance imaging of a symptomatic hemangioblastoma of the thoracic spine before tumor resection years earlier (the current lesions were not visible at that time; arrow indicates the lesion)

Our patient presented with VHL manifestations in the adnexae and in the spinal column. We report this case because only the gynecological findings prompted the definitive genetic tests. Our case report intends to make gynecologists aware that APMO could be a first manifestation of VHL disease. Since early diagnosis is relevant for long-term prognosis of the patient and its family, the gynecologist should trigger genetic tests and imaging studies to prove or rule out VHL disease.

Conflict of interest statement None.

\section{References}

1. Lonser RR, Glenn GM, Walther M et al (2003) von HippelLindau disease. Lancet 361:2059-2067

2. Joerger M, Koeberle D, Neumann HP, Gillessen S (2005) Von Hippel-Lindau disease: a rare disease important to recognize. Onkologie 28:159-163

3. de Paulsen N, Brychzy A, Fournier MC et al (2001) Role of transforming growth factor-alpha in von Hippel-Lindau (VHL) (-/-) clear cell renal carcinoma cell proliferation: a possible mechanism coupling VHL tumor suppressor inactivation and tumorigenesis. Proc Natl Acad Sci USA 98:1387-1392

4. Hes FJ, van der Luijt RB, Lips CJ (2001) Clinical management of von Hippel-Lindau (VHL) disease. Neth J Med 59:225-234

5. Jarrell ST, Vortmeyer AO, Linehan WM, Oldfield EH, Lonser RR (2006) Metastases to hemangioblastomas in von Hippel-Lindau disease. J Neurosurg 105:256-263

6. Neumann HP (1987) Prognosis of von Hippel-Lindau syndrome. Vasa 16:309-311

7. Mehta GU, Shively SB, Gläsker S et al (2007) Von Hippel-Lindau disease: epididymal cystadenoma targeted by metastatic events. Urology 69:1209.e9-e12 
8. Funk KC, Heiken JP (1989) Papillary cystadenoma of the broad ligament in a patient with von Hippel-Lindau disease. Am J Roentgenol 153:527-528

9. Gersell DJ, King TC (1988) Papillary cystadenoma of the mesosalpinx in von Hippel-Lindau disease. Am J Surg Pathol 12:145-149

10. Aydin H, Young RH, Ronnett BM, Epstein JI (2005) Clear cell papillary cystadenoma of the epididymis and mesosalpinx: immunohistochemical differentiation from metastatic clear cell renal cell carcinoma. Am J Surg Pathol 29:520-523

11. Gaffey MJ, Mills SE, Boyd JC (1994) Aggressive papillary tumor of middle ear/temporal bone and adnexal papillary cystadenoma.
Manifestations of von Hippel-Lindau disease. Am J Surg Pathol 18:1254-1260

12. Shen T, Zhuang Z, Gersell DJ, Tavassoli FA (2000) Allelic deletion of VHL gene detected in papillary tumors of the broad ligament, epididymis, and retroperitoneum in von Hippel-Lindau disease patients. Int J Surg Pathol 8:207-212

13. Werness BA, Guccion JG (1997) Tumor of the broad ligament in von Hippel-Lindau disease of probable mullerian origin. Int J Gynecol Pathol 16:282-285 